Historia y comunicación social

ISSN: 1137-0734

http://dx.doi.org/10.5209/hics.75702

\title{
La propaganda a través de los sellos postales de las colonias españolas en África (1924-1975)
}

\author{
Antonio Prieto Andrés
}

Recibido el: 18 de mayo de 2019 / Aceptado: 25 de junio de 2020

Resumen. Los sellos postales son creaciones de los estados que, además de ser medios de pago del correo, son también instrumentos de propaganda del estado emisor. Este papel propagandístico se dio especialmente en las metrópolis en relación con las emisiones postales específicas para sus áreas coloniales. En este trabajo se analizan los sellos de las colonias españolas en África (África Occidental Española, Fernando Poo, Guinea Española, Ifni, Protectorado Español en Marruecos, Río Muni, Sáhara Español y Tánger Español), durante el periodo 1924-1975. Utilizando el análisis de contenido cuantitativo se ha determinado cuáles son los temas principales y secundarios presentes, así como la actitud de la metrópoli hacia el colonizado que se muestra en los sellos.

Palabras clave: propaganda; colonialismo; sellos postales; Marruecos Español; Guinea Española.

[en] The propaganda through the postage stamps of the Spanish colonies in Africa (1924-1975)

\begin{abstract}
Postage stamps are creations of the states that, in addition to being means of payment of the mail, are also propaganda instruments of the issuing state. This propaganda role occurred especially in the metropolises in relation to specific postal issues for their colonial areas. This paper analyzes the stamps of the Spanish colonies in Africa (Spanish West Africa, Fernando Poo, Spanish Guinea, Ifni, Spanish Protectorate in Morocco, Muni River, Spanish Sahara and Spanish Tangier), during the period 1924-1975. Using the quantitative content analysis has been determined what are the main and secondary issues present, as well as the attitude of the metropolis towards the colonized that is shown on the stamps.
\end{abstract}

Keywords: propaganda; colonialism; postage stamps; Spanish Moroccov Spanish Guinea.

Sumario: 1. Introducción. 2. La propaganda a través de los sellos postales. 3. Las colonias españolas en África. 4. Fuentes y metodología. 5. Análisis de los resultados. 5.1. Las categorías temáticas presentes en los sellos de las colonias españolas en áfrica. 5.2. Las actitudes de la metrópoli hacia las colonias. 6. Conclusiones. 7. Referencias bibliográficas. 8. Notas.

Cómo citar: Prieto Andrés, A. (2021) La propaganda a través de los sellos postales de las colonias españolas en África (1924-1975), Historia y comunicación social 26(1), 79-94.

\section{Introducción}

En este trabajo queremos acercarnos a la relación entre poder y comunicación mediante el análisis de la propaganda realizada a través de los sellos postales de las colonias africanas de España entre 1924 y 1975, ya que su análisis permitirá descubrir cuáles son los mensajes que se fomentaron desde el estado, que es quien los emite, seleccionando sus temas, diseños y enfoques comunicativos (Navarro, 2010) para sus diversos públicos, internos y externos. Los sellos permiten realizar acercamientos diferentes de tipo histórico, político y/o comunicativo, ya que las imágenes que incluyen representan una época y nos remiten "al universo mental de la sociedad que la produce" (García, 2010: 222; Reid, 1984).

El sello postal contribuye, junto con los medios clásicos de comunicación de masas (radio, televisión y prensa), a la difusión de una "comunidad imaginada" en el sentido indicado por Anderson (2006) y, también, de la propaganda estatal. Los sellos postales son denominados "ventanas del estado" (Brunn, 2001), "retratos de la nación" (Schwarzenbach, 1999) o "embajadores de papel" (Altman, 1991). Son herramientas para la construcción nacional y para el moldeado de la memoria pública colectiva (Raento y Brunn, 2008; Reid, 1984; Brunn, 2001; Raento, 2006). El sello postal podría contribuir a ello al garantizar la visibilidad de los elementos

\footnotetext{
Universidad San Jorge, Zaragoza

E-mail: aprieto@usj.es

ORCID: https://orcid.org/0000-0001-5214-1794

Hist. comun. soc. 26(1) 2021: 79-94
} 
de la patria (desde la visión del estado) en objetos cotidianos, lo que prevendría que los ciudadanos olvidaran quiénes son (o se espera que sean) y a dónde pertenecen (Raento, 2006).

En este contexto, el objetivo general de este trabajo es analizar el contenido de los sellos postales como herramientas de la propaganda ideológica y cultural de la metrópoli española en sus colonias africanas durante el periodo 1924-1975.

Las preguntas de investigación, derivadas del objetivo general, son las siguientes:

- (PI1): ¿Cuáles son los temas principales y secundarios que se muestran en los sellos de las colonias españolas en África y que van a enmarcar los mensajes propagandísticos?

- (PI2) ¿Qué actitudes de la metrópoli hacia sus colonizados se observan en ellos?

- (PI3) ¿Qué distinciones se encuentran en las diversas áreas coloniales sobre las cuestiones anteriores?

El artículo se estructura en cinco apartados además de la introducción. En primer lugar, se establece el marco teórico, que explica el papel de los sellos postales como instrumentos de propaganda, especialmente en el ámbito colonial, para, en segundo término, hacer una breve reseña histórica de las colonias españolas en África; en tercer lugar, se explican las fuentes y la metodología; en cuarto término, se muestran los resultados obtenidos en la investigación. Se cierra el trabajo con un apartado de conclusiones.

\section{La propaganda a través de los sellos postales}

La propaganda es "the deliberate, systematic attempt to shape perceptions, manipulate cognitions, and direct behavior to achieve a response that furthers the desired intent of the propagandist" (Jowett y O'Donnell, 2012: 7). Está asociada al control y a la persuasión social, y supone un intento deliberado de alterar o mantener un equilibrio de poder que es ventajoso para el propagandista (Reig, 2004; Pizarroso, 1999).

Los sellos postales son documentos oficiales, emitidos por los estados, que sirven como medio de pago para el envío de documentos postales y que tienen un alcance internacional. Más allá de esta finalidad instrumental, los sellos postales tienen otras, claramente comunicativas: a) representan a la nación en el interior y en el exterior a través de símbolos reconocibles (banderas, escudos de armas, efigies de jefes de estado, etc.) y b) muestran aspectos o momentos particulares, seleccionados, de dicho país (Hoyo, 2010).

Existe una relación entre la comunicación visual y la transmisión de mensajes ideológicos. Raento y Brunn (2005:145) entienden que "when states emphasize 'the visual', which includes maps, postage stamps, currency, and official Web sites, they inform and educate their own populations and those beyond about where they are, who they are, and what they are about". Los sellos postales podrían mostrar solamente la denominación del país emisor y el valor postal (lo que se paga para transportar y entregar el sobre o paquete donde se insertan) de una forma simple y anodina. Sin embargo, desde muy pronto, los sellos comenzaron a incorporar contenidos visuales, icónicos (Hoek, 2002) cada vez más complejos, conforme la tecnología de elaboración e impresión lo iba permitiendo (Hoyo, 2010), sobre todo con la incorporación de los sellos denominados "conmemorativos" que presentan algún aspecto, evento o personaje que, a juicio del estado emisor, merece ser recordado (frente al sello denominado "definitivo" o "básico", cuyo diseño suele ser más aséptico, incorporando la imagen del Jefe del estado o de un símbolo representativo de la nación, como un escudo o alegoría, y que está pensado para los franqueos más habituales). Esto indica que el sello, desde muy pronto (en torno a 1920, cuando se generalizó el sello conmemorativo), comenzó a ser empleado por los estados para transmitir su propaganda (Stoetzer, 1953).

El estado elabora estos documentos oficiales a través de agencias o comités específicos que determinan el contenido y el diseño de cada emisión postal. Así, no es extraño que los sellos postales, como productos de estado, suelan ser eminentemente conservadores, venerando la versión de la realidad social más "respetable" (Altman, 1991). El autor ofrece una visión del sello como un producto oficial en el que el estado emisor muestra, de modo premeditado, la percepción que quiere de sí mismo y del mundo: "they are both miniature art works and pieces of government propaganda: they can be used to promote sovereignty, celebrate achievements, define national, racial, religious or linguistic identity, portray messages or exhort certain behaviour" (Altman, 1991: 2).

Los sellos pueden considerarse un elemento más de la iconografía del estado y su "política visual". Deans y Dobson (2005: 3) entienden que "stamps can and should be read as texts, often with expressly political purposes or agendas which are conveyed through the images they depict". "Postage stamps," continúan Deans y Dobson (2005:6) "emerge as vehicles for identity creation and propagation, and as mechanisms for regime legitimation. They demonstrate changing concepts of the state over time and the changing aspirations of state elites". Durante la Guerra Civil Española los bandos contendientes hicieron un abundante uso del sello postal (y, especialmente, de las viñetas, que se asemejan a los sellos postales, pero que no tienen valor oficial de franqueo) como herramienta propagandística, para aumentar la moral de las poblaciones bajo su control y para diseminar sus respectivas ideologías. El sello postal nos muestra así las estrategias comunicativas de 
los gobiernos, reflejando una dimensión cultural y política de la sociedad donde circula el mensaje filatélico (Hoek y Scott, 1993), por lo que no son neutrales o partes sin importancia de material cultural, sino portadores de imágenes potentes de la ideología estatal dominante (Cusack, 2005). Se trata de un medio de emisión de ideología (Navarro, 2010) que, con el tiempo, pasó a adquirir valores propios de un cartel publicitario y propagandístico (Stoetzer, 1953). En la misma línea, Satué (2011) se refiere al sello de correos como un cartel en miniatura, con quien comparte los principios de síntesis e impacto visuales que definen al cartelismo. Además, los mensajes pueden ser entregados de forma sutil e inconsciente, pero la repetición (al ver el mismo diseño postal muchas veces) consolida la eficacia del mensaje (Child, 2005).

Dado que la mayor parte del periodo analizado en este trabajo transcurre durante la Dictadura franquista, es necesario hacer referencia a la norma jurídica que estableció, a partir de 1944, los criterios que iban a definir las temáticas prioritarias en las emisiones postales de este periodo, dado que el sello es considerado aquí: "Símbolo de soberanía, portador de valores espirituales e históricos en cuanto viene a ser expresión de la entidad autónoma Nacional, el sello perpetúa, pasada su momentánea función de franqueo, esa significación a los ojos de la posteridad por obra y efecto del coleccionismo" (Orden de 5 de Julio de 1944 por la que se fija el plan iconográfico en la elaboración de sellos de correos). Más concretamente, los temas que se determinaron como prioritarios fueron los siguientes:

1. Simbolización del Estado y la Soberanía. El Jefe del Estado.

2. Iconografía histórica española. Grandes personalidades españolas: historia política, militar, naval, religiosa, cultural, artística y literaria.

3. Iconografía de acción de España en el mundo: descubridores y conquistadores; evangelizadores y misioneros; figuras de la historia cultural de España en el mundo.

4. Iconografía de las creaciones españolas: creaciones literarias y del arte español.

5. Monumentos españoles: en España y fuera de España.

6. Paisajes españoles: de valor histórico y de valor pintoresco o representativo.

En el ámbito de la ocupación colonial, los sellos postales emitidos por las metrópolis específicamente para sus colonias tuvieron un papel propagandístico muy relevante. Para Scott (2002) las imágenes presentes en los sellos coloniales tienen una finalidad más de apropiación colonialista que de análisis antropológico, sustituyendo la realidad de la vida indígena por una mera imagen arbitraria y simbólica. Para este autor, los temas son restringidos, abundando los tipos indígenas, la caza y la agricultura, la flora y la fauna, los rituales o las máscaras. Adedze (2004) añade a estos los temas de obras públicas, pueblos y arquitectura, recursos económicos, escenarios locales y sitios arqueológicos.

La función propagandística del sello colonial, con profusión de imágenes etnográficas, es, para Scott (2002), atraer a nuevos colonos y promover el prestigio cultural y científico (en su análisis, de Francia), y seducir a los coleccionistas europeos, sobre todo a los jóvenes. Otra finalidad propagandística importante es reforzar la imagen de potencia colonial de la metrópolis, favoreciendo el nacionalismo, algo en lo que coinciden Adedze (2004) al analizar el caso de Francia, Cusack (2005) el de Portugal, o Altman (1991) para Gran Bretaña, si bien este introduce un importante matiz que debe valorarse en los sellos coloniales: que debe evitar ofender a la población autóctona, introduciendo en las emisiones sellos de líderes locales.

\section{Las colonias españolas en África}

Las colonias o territorios bajo dominio español en África y cuyos sellos vamos a analizar son: a) Protectorado español en Marruecos, b) Tánger, c) África Occidental Española (AOE) y d) Guinea Española. Hagamos una breve reseña histórica de cada uno de ellos.

a) El Protectorado español en Marruecos, comúnmente conocido como Marruecos Español, nació de los acuerdos franco-españoles de 27 de noviembre de 1912. El Marruecos Español (ver Gráfico 1) estaba compuesto de dos zonas: la zona norte, más extensa, que incluía las regiones del Rif y Yebala; y la zona sur, conocida como Cabo Juby, que lindaba con la colonia española del Sáhara español al sur, y al norte con el área del protectorado francés en Marruecos. El protectorado duraría hasta el día 7 de abril de 1956, salvo la zona sur que España administraba unida al Sáhara español, y que fue entregada a Marruecos en 1958 (Vilar, 2005).

Como antecedentes previos, son varias las guerras por controlar el territorio, como las guerras en el Rif (la primera en 1893-1894 y la segunda, más larga y cruenta, entre 1911-1927) que tuvieron un profundo impacto en la sociedad española y que provocaron que su visión del "moro" fuera bastante negativa. Tras la debacle colonial de España en 1898 (pérdida de Cuba, Puerto Rico y Filipinas) el Marruecos Español se consideraba la joya del colonialismo español, más por su carga simbólica y su relativa importancia geoestratégica que por sus pobres recursos y nula rentabilidad (De- Madariaga, 2013).

b) La Zona Internacional de la ciudad de Tánger (Marruecos) fue un protectorado ejercido por varios países entre 1923 y 1956 (Estatuto de Tánger de 1923). Entre 1940 y 1945, aprovechando la ocupación alemana 
de Francia, fue suspendido el protectorado internacional sobre la ciudad, ejerciendo la España de Franco la soberanía efectiva al integrarla en su zona del protectorado marroquí (Suárez-Blanco, 1997).

Gráfico 1. Los territorios coloniales del Magreb Occidental en 1955

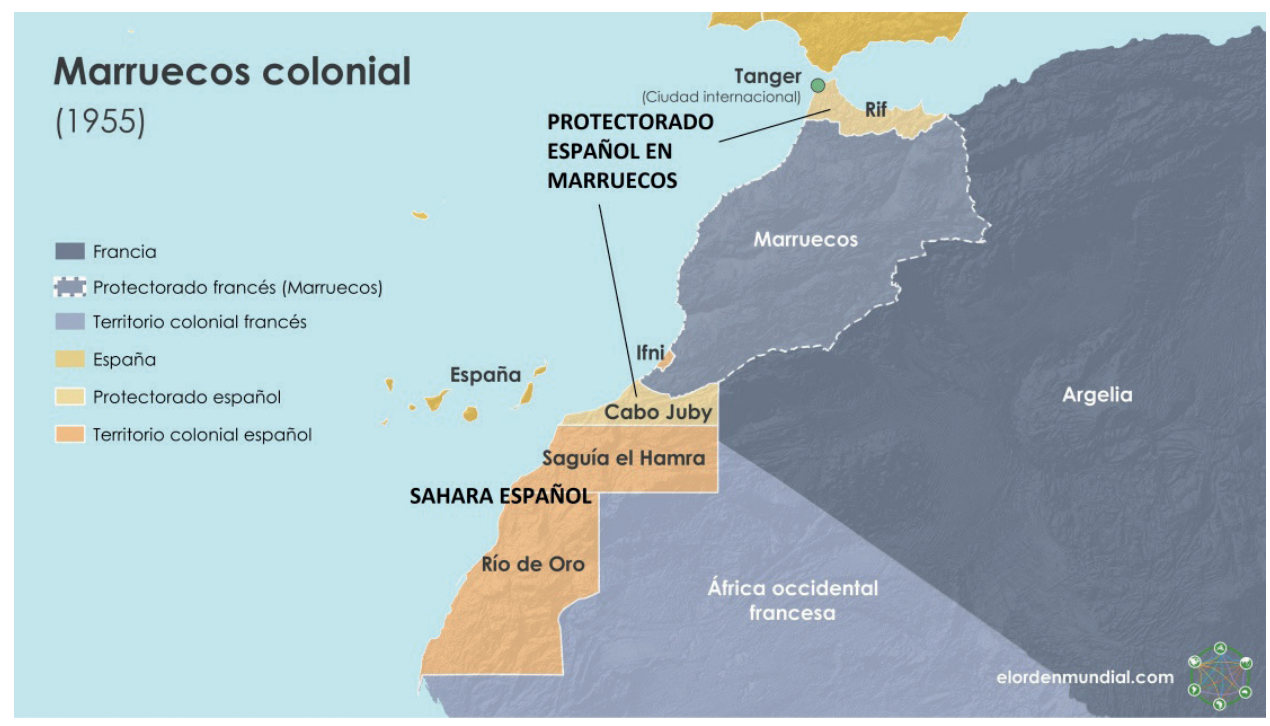

Fuente: Adaptado de: https://elordenmundial.com/amigos-con-intereses-espana-y-el-mundo-arabe/

c) África Occidental Española (AOE) fue el nombre de la agrupación de colonias españolas en el noroeste de África, que existió entre 1946 y 1958. Incluía los territorios de Ifni, Cabo Juby (zona sur del Marruecos Español), Saguía el Hamra y Río de Oro. El 14 de enero de 1958, tras el conflicto de Ifni entre España y Marruecos, la agrupación dejó de existir. Cabo Juby fue cedido a Marruecos (abril de 1958). Río de Oro y Saguía el Hamra formaron la provincia española de ultramar del Sáhara español, en tanto que Ifni formó otra provincia española de ultramar.

Ifni era un pequeño territorio al suroeste de Marruecos, bajo dominio español a partir de 1860 (Tratado de Tetuán). La retrocesión de Ifni a Marruecos se produjo en 1969, si bien, ya desde 1958, la administración española era efectiva sólo en las inmediaciones de la capital, Sidi Ifni, ya como provincia española.

El Sáhara español era un territorio casi desértico de $266.000 \mathrm{~km}^{2}$. Reclamado como territorio por España en diciembre de 1884, y delimitado tras negociaciones con Francia entre 1900 y 1912, la ocupación del territorio se realizó muy lentamente en las dos décadas siguientes. En 1958 se declaró al Sáhara Español como una provincia más de la metrópoli. La riqueza más destacable de esta área en la época analizada es de tipo mineral: los fosfatos. El 6 de noviembre de 1975 la "Marcha Verde" (organizada por el rey Hassan II de Marruecos) y formada por 50.000 civiles, traspasó la frontera del Sáhara Español desde el país vecino, para retirarse pocos días después tras un llamamiento del Consejo de Seguridad de Naciones Unidas, en su Resolución 380. En virtud de los Acuerdos de Madrid de 1975, con España ya decidida a descolonizar, se estableció una administración temporal tripartita constituida por España, Marruecos y Mauritania, para organizar un referéndum de autodeterminación que aún no se ha celebrado, más de 40 años después, puesto que Marruecos se hizo enseguida con el control de la mayor parte del territorio, tras la inhibición de los otros dos países.

d) Finalmente, la Guinea Española (ver Gráfico 2) era un territorio de apenas $28.000 \mathrm{~km}^{2}$, situado en el África ecuatorial. La creación de la Guinea Española fue consecuencia de la cesión de Portugal a España, mediante los tratados de San Ildefonso (1777) y El Pardo (1778), de las islas de Fernando Poo y Annobón, más las islas de Elobey y Corisco (1843) y la zona de cabo San Juan, junto a la desembocadura del estuario del río Muni, ya en el continente africano. El Tratado de París, de 27 de marzo de 1900, entre Francia y España, y el de Berlín (1885) con Alemania, fijaron los límites definitivos de la colonia (Campos-Serrano, 2000).

Guinea Ecuatorial fue calificada desde el principio como una colonia de explotación comercial de cacao, café y madera (Álvarez-Chillida y Nerín, 2018; Suárez-Blanco, 1997). En 1959 España convirtió el estatus jurídico de sus colonias en "provincias africanas", siguiendo el modelo portugués. En 1963 incluso concedió la autonomía a la "Región Ecuatorial", constituida por las provincias de Fernando Poo y Río Muni, que pasó a llamarse oficialmente Guinea Ecuatorial, a pesar de que en la metrópoli no se dio un régimen autonómico similar en esta época. Finalmente, España concedió la independencia a todo el territorio en 1968. 
Gráfico 2. Los territorios españoles del Golfo de Guinea hacia 1945

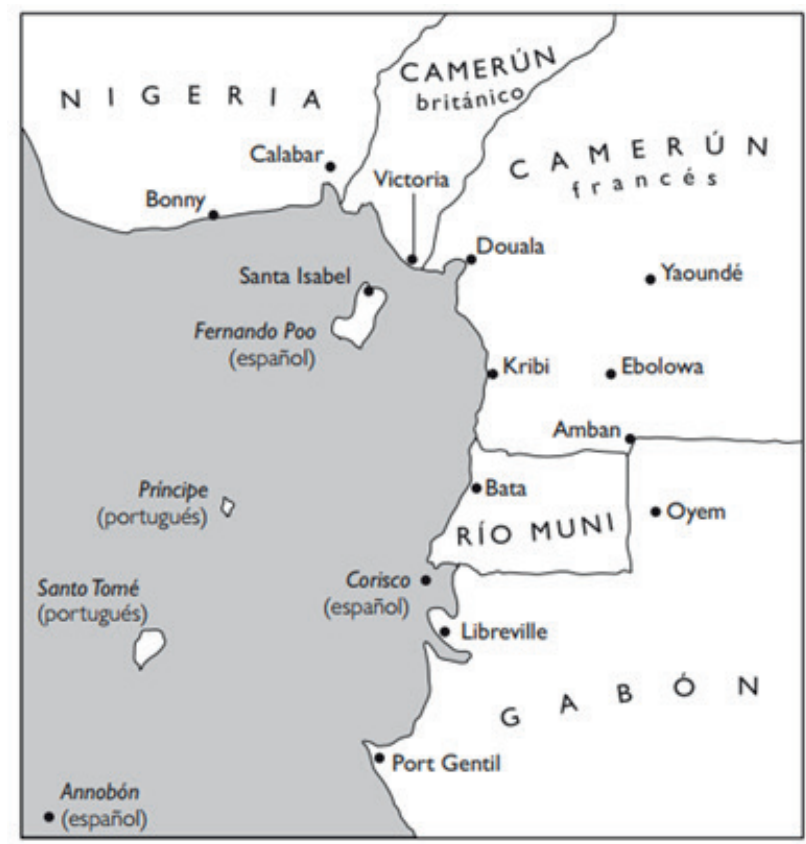

Fuente: Álvarez-Chillida y Nerín (2018: 31)

El sistema colonial español estaba inspirado en la cultura política (autoritaria durante la dictadura franquista, entre 1937-1975, que cubre buena parte del periodo analizado) de la metrópoli, y, como consecuencia, mostraba un escaso respeto por la diversidad cultural, lingüística y étnica de las poblaciones locales. Según Álvarez-Chillida y Nerín (2018: 20-21): "Frente al colonialismo inglés, que permitió la supervivencia de determinados elementos culturales africanos, como las lenguas autóctonas, usadas en las escuelas, el español fue especialmente destructor de las culturas nativas".

En el Marruecos Español la visión colonial fue paternalista (De-Madariaga, 2013: 191) e incluso de cierta tolerancia política y religiosa durante el franquismo. En cambio, en Guinea se basó en el asimilacionismo, por la conversión de los nativos en buenos españoles, católicos y trabajadores para el mercado. Se trataba de un paternalismo exacerbado (Pelissier, 1964), pues aunque defendía combatir las salvajes costumbres de los colonizados, no les creía capaces de asimilar la cultura europea a corto plazo, por lo que se limitó extraordinariamente el acceso de los nativos a la educación y a los empleos cualificados.

El "imperio africano" de España jamás tuvo la importancia económica, demográfica y estratégica que tuvieron sus respectivas colonias para Francia, Portugal, Bélgica o Gran Bretaña. Y, dentro de él, la prioridad absoluta para el Gobierno siempre fue Marruecos (desde su pacificación en 1926, el departamento de asuntos coloniales español se denominaba Dirección General de Marruecos y Colonias). Además, las campañas militares en el protectorado, que se extendieron hasta 1927, generaron un gran rechazo popular en España, por los costes humanos y económicos que supusieron. Por ello, el colonialismo español en África careció del apoyo generalizado que se dio en otras potencias (Álvarez-Chillida y Nerín, 2018).

\section{Fuentes y metodología}

Las fuentes utilizadas para este trabajo son los sellos postales emitidos específicamente para las ocho zonas coloniales españolas en África durante el periodo 1924-1975: AOE (1949-1951); Fernando Poo (1960-1968); Guinea Española (1924-1959); Ifni (1943-1968); Protectorado Español en Marruecos (1928-1957); Río Muni (1960-1968); Sáhara Español (1924-1975) y Tánger Español (1948).

El periodo temporal elegido deriva del tipo de sellos seleccionados: solo se han analizado los sellos "conmemorativos", eliminando los "definitivos" o "básicos", cuya diferencia ya se ha explicado, y que se han obviado por su falta de contenido interpretativo a efectos de este trabajo. Así, los primeros sellos conmemorativos en alguna de estas colonias se emitieron en 1924 (Guinea y Sáhara) y el último, en 1975 (Sáhara). En total, el corpus para este trabajo lo componen 667 sellos, distribuidos según se muestra en la Tabla 1. 
Tabla 1. Sellos conmemorativos de las colonias españolas en África (1924-1975). No y porcentaje

\begin{tabular}{|c|c|c|c|c|c|c|c|c|c|}
\hline & $A O E$ & $\begin{array}{c}\text { Fernando } \\
\text { Poo } \\
\end{array}$ & $\begin{array}{c}\text { Guinea } \\
\text { Española }\end{array}$ & Ifni & $\begin{array}{c}\text { Marruecos } \\
\text { Español }\end{array}$ & $\begin{array}{c}\text { Río } \\
\text { Muni }\end{array}$ & $\begin{array}{l}\text { Sáhara } \\
\text { Español }\end{array}$ & $\begin{array}{c}\text { Tánger } \\
\text { Esp. }\end{array}$ & Total \\
\hline $\mathrm{N}^{0}$ de sellos & 10 & 51 & 62 & 104 & 216 & 51 & 162 & 11 & 667 \\
\hline Porcentaje & 1,5 & 7,6 & 9,3 & 15,6 & 32,4 & 7,6 & 24,3 & 1,6 & 100 \\
\hline
\end{tabular}

Fuente: Elaboración propia

Marruecos Español es la colonia que recibe mayor atención filatélica con 216 sellos (32,4\%), a pesar de que se independizó en 1956. Esto refleja la importancia de esta área para las autoridades, como fuente de prestigio colonial, como ya se ha explicado. Le sigue el Sáhara Español (162 sellos; 24,3\%), algo lógico si se valora que fue la última colonia en desvincularse de España (1975). Es reseñable el peso de Ifni, un minúsculo territorio que, sin embargo, agrupa el 15,6\% del total de sellos emitidos (104), a pesar de separarse de España en 1968.

Por periodos, los sellos analizados se dividen de la siguiente manera (Gráfico 3):

Gráfico 3. Distribución de los sellos por regímenes políticos y décadas

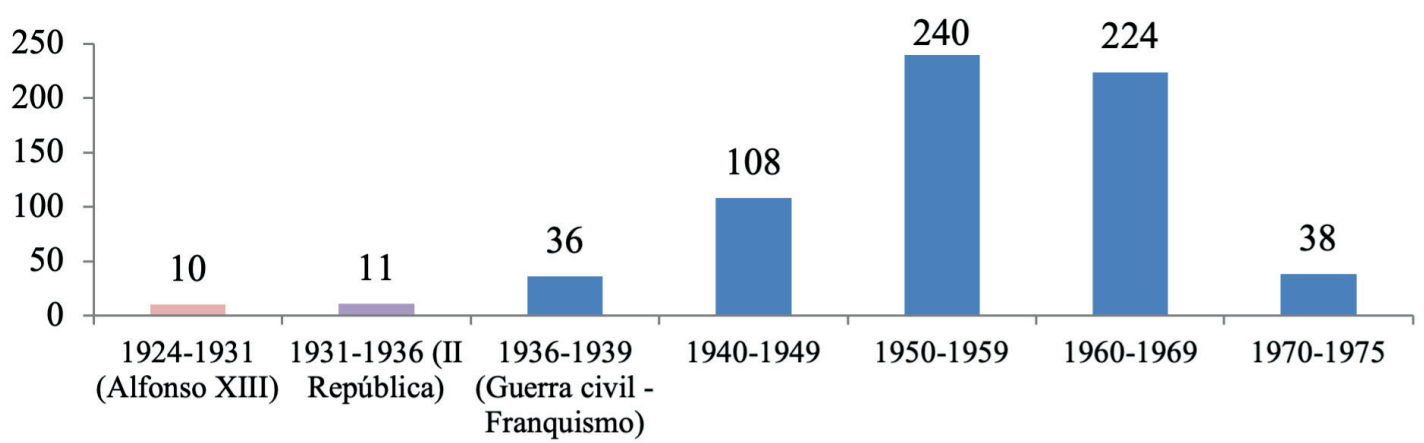

Fuente: Elaboración propia

Se observa que la mayor parte de los sellos (646) corresponden al periodo de la Dictadura franquista, mientras solo 10 se emitieron durante los últimos años del reinado de Alfonso XIII y 11 durante la II República. El periodo 1936-1939 se adjudica al franquismo ya que fue quien dominó esta zona desde el principio y emitió sus sellos. Se podría haber acotado el estudio al periodo franquista, pero no es el objetivo de este trabajo. Se observa que las décadas de mayor emisión son las de 1950 y 1960 . Hay que tener en cuenta que son épocas de incremento de emisiones filatélicas en todas las colonias. La drástica reducción de los años 70 se explica porque ya solo pervive el Sáhara como colonia.

Hay que aclarar que en las siguientes tablas se ha optado por agrupar los datos de las colonias en tres grandes "áreas coloniales": a) AOE, que agrupa los sellos emitidos con esta denominación más los de Sáhara e Ifni; b) Guinea Española, que engloba los de esta denominación más los de Fernando Poo y Río Muni y c) Marruecos Español más Tánger. Se ha hecho así por coherencia geográfica y cultural y para aligerar de datos las tablas, haciéndolas más comprensibles.

Para conseguir los objetivos propuestos, se ha optado por el análisis de contenido cuantitativo como metodología de investigación de los sellos postales seleccionados. Este método gira en torno a las herramientas estadísticas empleadas para obtener los datos descriptivos de una serie de variables. Para Berelson (1952: 18) el análisis de contenido se trata de una herramienta "para la descripción objetiva, sistemática y cuantitativa" de los textos comunicativos. Krippendorf (1980) lo considera una forma de comprender las cualidades simbólicas de textos en relación con contextos culturales más amplios y es adecuado cuando se trabaja con un número significativo de unidades de análisis. Las imágenes también pueden ser analizadas a través de este método, como hicieron Lutz y Collins (1993) con una serie de fotografías, combinándolo con otros métodos, en su estudio sobre la representación del "otro" en la revista National Geographic y que ha servido como importante inspiración para este trabajo. A la hora de diseñar el proceso de análisis de los sellos postales, se partió de diversos trabajos, como el de Rose (2001) y Mirzoeff (1998) para los aspectos más puramente visuales del análisis, así como los de Brunn (2001), Child (2005), García (2010), Gozalbes (2011), Moriente (2013), Navarro (2013), Raento y Brunn (2005; 2008), Raento (2006) y Reid (1984) para definir todas las variables a analizar en el corpus, si bien en este trabajo se presenta solo una parte.

A partir de todo este material se codificaron una serie de variables en los 667 sellos analizados. Aquí se presentan los resultados relacionados con las temáticas principales y secundarias que aparecen en ellos. La temática va a definir el contenido esencial del mensaje y nos ha permitido establecer categorías que pueden 
ser asociadas a referentes ideológicos del emisor, tal como quedó ejemplificado al reseñar el plan iconográfico nacional (1944).

En todos los sellos existe siempre una temática principal, mientras que solo en 359 aparece, además, una temática secundaria. Se trata de los casos en los que la categoría temática principal no cubre completamente la totalidad de lo expresado en el sello. Así, un sello de una flor o un animal quedaría cubierto completamente por el tema principal "Flora y fauna". Sin embargo, un sello en el que, por ejemplo, apareciera un indígena en primer plano tocando un instrumento musical, estaría en la categoría principal "Cultura y folclore autóctono" y, como temática secundaria, en la de "Tipos indígenas".

Además, como segunda cuestión destacada analizada se ha codificado, para cada una de las colonias, la "actitud de la metrópoli" que se deriva de un análisis de conjunto de cada sello, incluyéndola en una de las siguientes variables: "Neutra o no se identifica", "Deja vivir libre", "Domina", "Civiliza", "Evangeliza", "Conviven colonizador y colonizado" u "Oprime". Este análisis ha permitido establecer, en cierta medida, la intencionalidad del emisor a lo largo de todo el periodo y las particularidades de las colonias, así como la visión de conjunto que permanece.

\section{Análisis de los resultados}

En este epígrafe se ofrecen los resultados de la investigación, estructurados en dos áreas: 1) cuáles son los temas principales y secundarios presentes en los sellos analizados y 2) cuál es la actitud de la metrópoli que se muestra en ellos.

\subsection{Las categorías temáticas presentes en los sellos de las colonias españolas en África}

La Tabla 2 presenta cuáles son las temáticas principales en los sellos analizados, dentro y entre las colonias objeto de estudio.

Tabla 2. Temas principales que aparecen en los sellos ( $\mathrm{N}^{\mathrm{o}}$ y \% dentro de cada área colonial y entre ellas)

\begin{tabular}{|c|c|c|c|c|c|c|c|c|c|c|c|}
\hline COLONIA & $\mathrm{AOI}$ & SÁHAR & A+IFNI) & $\begin{array}{l}\text { GU } \\
\text { NA }\end{array}$ & $\begin{array}{l}\text { JEA ESI } \\
\text { DO POC } \\
\text { MUNI }\end{array}$ & $\begin{array}{l}\text { RER- } \\
\text { RÍO }\end{array}$ & & $\begin{array}{l}\text { RUECC } \\
\text { TÁNG }\end{array}$ & ESP. + & & TAL \\
\hline TEMA PRINCIPAL & $N^{o}$ & $\begin{array}{c}\% \\
\text { dentro } \\
\text { de la } \\
\text { colonia }\end{array}$ & $\begin{array}{l}\% \text { entre } \\
\text { colonias }\end{array}$ & $N^{o}$ & $\begin{array}{c}\% \\
\text { dentro } \\
\text { de la } \\
\text { colo- } \\
\text { nia }\end{array}$ & $\begin{array}{c}\% \\
\text { entre } \\
\text { colo- } \\
\text { nias }\end{array}$ & $N^{o}$ & $\begin{array}{l}\% \text { den- } \\
\text { tro de la } \\
\text { colonia }\end{array}$ & $\begin{array}{c}\% \text { entre } \\
\text { colo- } \\
\text { nias }\end{array}$ & $N^{o}$ & $\begin{array}{c}\% \\
\text { dentro } \\
\text { de la } \\
\text { colonia }\end{array}$ \\
\hline Flora y fauna & 115 & $41,7 \%$ & $63,5 \%$ & 66 & $40,2 \%$ & $36,5 \%$ & 0 & $0,0 \%$ & $0,0 \%$ & 181 & $27,1 \%$ \\
\hline Sanidad & 1 & $0,4 \%$ & $1,8 \%$ & 1 & $0,6 \%$ & $1,8 \%$ & 54 & $23,8 \%$ & $96,4 \%$ & 56 & $8,4 \%$ \\
\hline $\begin{array}{l}\text { Pueblos y arquitectu- } \\
\text { ra civil }\end{array}$ & 3 & $1,1 \%$ & $5,5 \%$ & 2 & $1,2 \%$ & $3,6 \%$ & 50 & $22,0 \%$ & $90,9 \%$ & 55 & $8,2 \%$ \\
\hline Tipos indígenas & 27 & $9,8 \%$ & $70,3 \%$ & 2 & $1,2 \%$ & $5,4 \%$ & 8 & $3,5 \%$ & $21,6 \%$ & 37 & $5,5 \%$ \\
\hline $\begin{array}{l}\text { Cultura y folclore au- } \\
\text { tóctono }\end{array}$ & 9 & $3,3 \%$ & $26,5 \%$ & 9 & $5,5 \%$ & $26,5 \%$ & 16 & $7,0 \%$ & $47,1 \%$ & 34 & $5,1 \%$ \\
\hline Motivos postales & 14 & $5,1 \%$ & $42,4 \%$ & 3 & $1,8 \%$ & $9,1 \%$ & 16 & $7,0 \%$ & $48,5 \%$ & 33 & $4,9 \%$ \\
\hline Personajes ilustres & 13 & $4,7 \%$ & $40,0 \%$ & 7 & $4,3 \%$ & $23,3 \%$ & 10 & $4,4 \%$ & $33,3 \%$ & 30 & $4,5 \%$ \\
\hline Paisajes & 7 & $2,5 \%$ & $12,0 \%$ & 6 & $3,7 \%$ & $24,0 \%$ & 12 & $5,3 \%$ & $48,0 \%$ & 25 & $3,7 \%$ \\
\hline $\begin{array}{l}\text { Economía agrícola, } \\
\text { caza y pesca }\end{array}$ & 6 & $2,2 \%$ & $20,8 \%$ & 6 & $3,7 \%$ & $25,0 \%$ & 12 & $5,3 \%$ & $50,0 \%$ & 24 & $3,6 \%$ \\
\hline $\begin{array}{l}\text { Cultura de la metró- } \\
\text { poli }\end{array}$ & 12 & $4,3 \%$ & $54,5 \%$ & 10 & $6,1 \%$ & $45,5 \%$ & 0 & $0,0 \%$ & $0,0 \%$ & 22 & $3,3 \%$ \\
\hline Temática militar & 1 & $0,4 \%$ & $4,8 \%$ & 0 & $0,0 \%$ & $0,0 \%$ & 20 & $8,8 \%$ & $95,2 \%$ & 21 & $3,1 \%$ \\
\hline Deportes & 12 & $4,3 \%$ & $57,1 \%$ & 9 & $5,5 \%$ & $42,9 \%$ & 0 & $0,0 \%$ & $0,0 \%$ & 21 & $3,1 \%$ \\
\hline Transportes & 11 & $4,0 \%$ & $42,1 \%$ & 3 & $1,8 \%$ & $15,8 \%$ & 5 & $2,2 \%$ & $26,3 \%$ & 19 & $2,8 \%$ \\
\hline Cristianismo & 3 & $1,1 \%$ & $16,7 \%$ & 15 & $9,1 \%$ & $83,3 \%$ & 0 & $0,0 \%$ & $0,0 \%$ & 18 & $2,7 \%$ \\
\hline $\begin{array}{l}\text { Símbolos del estado/ } \\
\text { colonia }\end{array}$ & 11 & $4,0 \%$ & $68,8 \%$ & 5 & $3,0 \%$ & $31,3 \%$ & 0 & $0,0 \%$ & $0,0 \%$ & 16 & $2,4 \%$ \\
\hline
\end{tabular}




\begin{tabular}{|l|c|c|c|c|c|c|c|c|c|c|c|}
\hline Efemérides / eventos & 6 & $2,2 \%$ & $42,9 \%$ & 7 & $4,3 \%$ & $50,0 \%$ & 1 & $0,4 \%$ & $7,1 \%$ & 14 & $2,1 \%$ \\
\hline Comercio y artesanía & 1 & $0,4 \%$ & $8,3 \%$ & 1 & $0,6 \%$ & $8,3 \%$ & 10 & $4,4 \%$ & $83,3 \%$ & 12 & $1,8 \%$ \\
\hline Obras públicas & 5 & $1,8 \%$ & $62,5 \%$ & 0 & $0,0 \%$ & $0,0 \%$ & 3 & $1,3 \%$ & $37,5 \%$ & 8 & $1,2 \%$ \\
\hline Exploración & 3 & $1,1 \%$ & $42,9 \%$ & 4 & $2,4 \%$ & $57,1 \%$ & 0 & $0,0 \%$ & $0,0 \%$ & 7 & $1,0 \%$ \\
\hline Infancia & 4 & $1,4 \%$ & $57,1 \%$ & 3 & $1,8 \%$ & $42,9 \%$ & 0 & $0,0 \%$ & $0,0 \%$ & 7 & $1,0 \%$ \\
\hline Economía industrial & 3 & $1,1 \%$ & $50,0 \%$ & 0 & $0,0 \%$ & $0,0 \%$ & 3 & $1,3 \%$ & $50,0 \%$ & 6 & $0,9 \%$ \\
\hline Islam & 3 & $1,1 \%$ & $50,0 \%$ & 0 & $0,0 \%$ & $0,0 \%$ & 3 & $1,3 \%$ & $50,0 \%$ & 6 & $0,9 \%$ \\
\hline Mapa & 2 & $0,7 \%$ & $40,0 \%$ & 2 & $1,2 \%$ & $40,0 \%$ & 1 & $0,4 \%$ & $20,0 \%$ & 5 & $0,7 \%$ \\
\hline Otros & 0 & $0,0 \%$ & $0,0 \%$ & 1 & $0,6 \%$ & $25,0 \%$ & 3 & $1,3 \%$ & $75,0 \%$ & 4 & $0,6 \%$ \\
\hline Educación & 1 & $0,4 \%$ & $33,3 \%$ & 2 & $1,2 \%$ & $66,7 \%$ & 0 & $0,0 \%$ & $0,0 \%$ & 3 & $0,4 \%$ \\
\hline Alegoría & 2 & $0,7 \%$ & $100,0 \%$ & 0 & $0,0 \%$ & $0,0 \%$ & 0 & $0,0 \%$ & $0,0 \%$ & 2 & $0,3 \%$ \\
\hline Valores cívicos & 1 & $0,4 \%$ & $100,0 \%$ & 0 & $0,0 \%$ & $0,0 \%$ & 0 & $0,0 \%$ & $0,0 \%$ & 1 & $0,1 \%$ \\
\hline $\begin{array}{l}\text { TOTAL ENTRE CO- } \\
\text { LONIAS }\end{array}$ & 276 & $100 \%$ & $39,9 \%$ & 164 & $100 \%$ & $24,6 \%$ & 227 & $100 \%$ & $34,0 \%$ & 667 & $100 \%$ \\
\hline
\end{tabular}

Fuente: Elaboración propia

La tabla se ha ordenado de forma descendente a partir del mayor número de sellos por tema en el conjunto de las colonias. Así, la temática más repetida es la relativa a "Flora y fauna" (Imágenes 1-3), que aparece como principal en 181 sellos $(27,1 \%)$ de los 667 analizados. Este tema está más presente en Africa Occidental (63,5\% del total de esta temática) y en Guinea Española (36,5\%), mientras que en Marruecos Español nunca se ha utilizado como recurso principal.

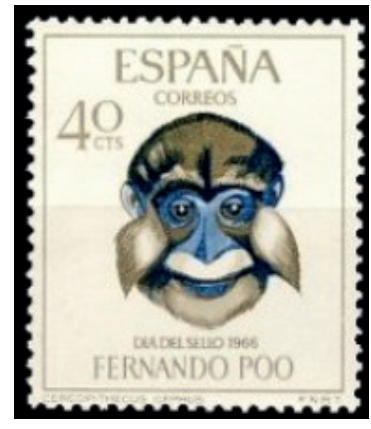

Imagen 1. Fernando Poo (1966).

Cercopiteco de hocico azul ${ }^{1}$

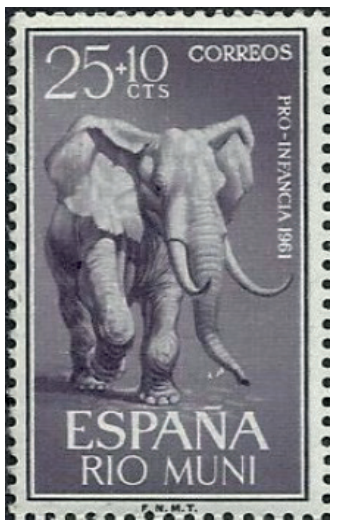

Imagen 2. Río Muni (1961). Elefante. Loxodonta africana

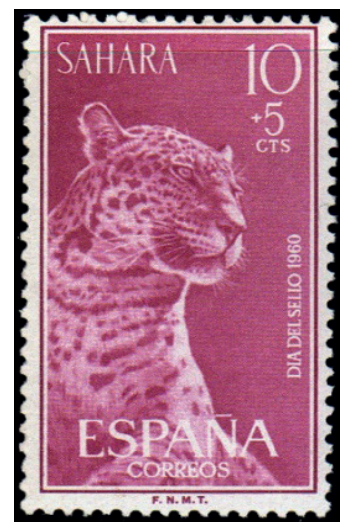

Imagen 3. Sáhara (1960). Leopardo. Panthera Pardus.

La sanidad (Imágenes 4-5) es el segundo tema principal, ya a mucha distancia, pues aparece en 56 sellos (8,4\% del total). Es un asunto especialmente empleado en Marruecos Español (96,4\% del total). Se trata de referencias a centros sanitarios y a la curación de enfermedades, casi siempre la tuberculosis, muy presente en esta área en las décadas de los años 1940-1950.

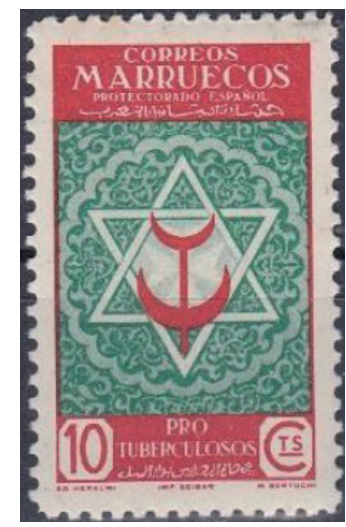

Imagen 4. Marruecos Español (1946). Arabesco y símbolo pro-tuberculosos

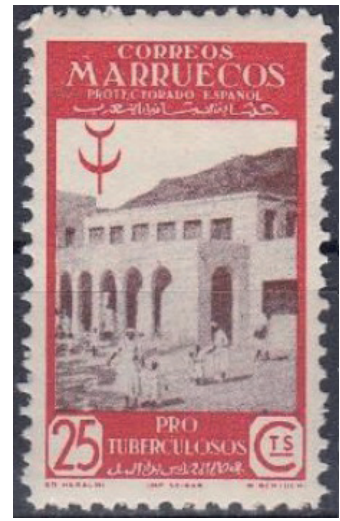

Imagen 5. Marruecos Español (1946). Sanatorio 
Le sigue de cerca la temática de "Pueblos y arquitectura civil" (Imágenes 6-7) (55 sellos y 8,2\% del total), de nuevo gracias a su abundantísimo empleo en los sellos de Marruecos Español (90,9\% del total, comparando entre colonias). Sin duda, la mayor urbanización de esta zona en comparación con Guinea y AOE es una de las causas evidentes de su importante presencia, junto con el hecho de que el autor de la inmensa mayoría de los sellos de Marruecos Español durante el periodo 1928-1955 fue el artista Mariano Bertuchi, quien tenía especial predilección por esta temática.

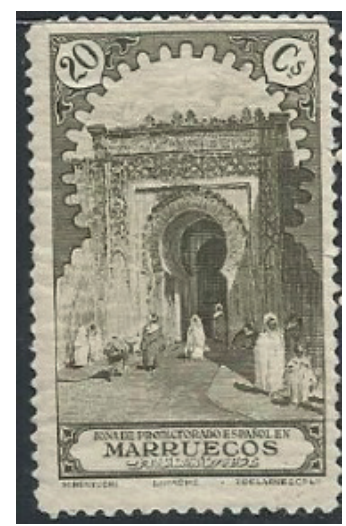

Imagen 6. Marruecos Español (1928). Puerta de Larache

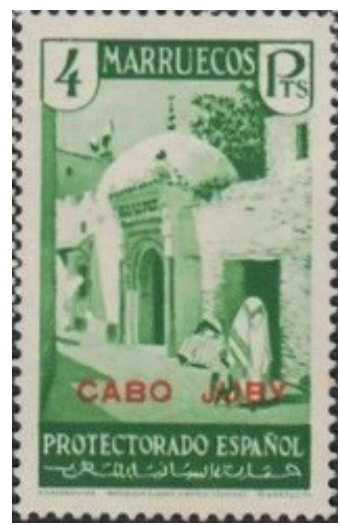

Imagen 7. Marruecos Español (Cabo Juby) (1946). Alcazarquivir

En cuarta posición aparece la categoría de "Tipos indígenas" (Imágenes 8-10), donde se observan diferentes presentaciones de personas autóctonas, claramente identificadas por sus rasgos étnicos y vestimenta propias. Suponen el 5,5\% del total (37 sellos). Es en los sellos del AOE donde esta temática es más clara (70,3\% del total en comparación con las demás áreas).

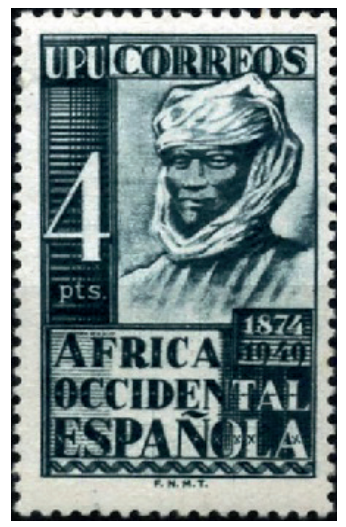

Imagen 8. África Occidental Española (1949). 75 aniversario de la Unión Postal

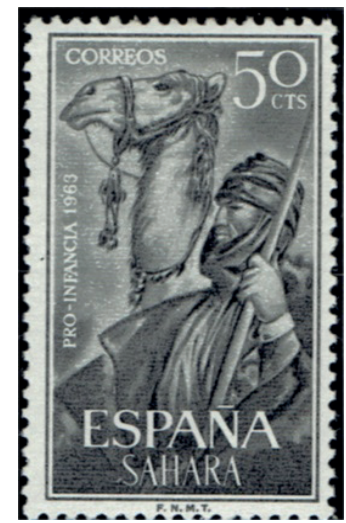

Imagen 9. Sáhara Español (1963). Indígenas con dromedarios

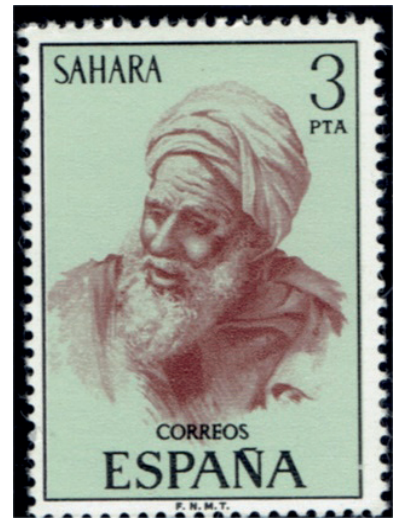

Imagen 10. Sáhara Español

(1975). Saharaui

La quinta categoría temática se refiere a "Cultura y folclore autóctono" (Imágenes 11-13) y en ella se pueden apreciar aspectos relacionados con la vida de las personas nativas, tales como tradiciones, celebraciones, música, juegos u otros eventos populares. Son el 5,1\% del total (34 sellos) y aparecen más en Marruecos Español (47,1\% del total en relación con las demás áreas).

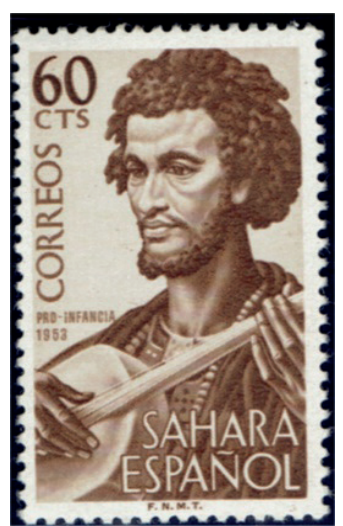

Imagen 11. Sáhara Español (1953). Músicos

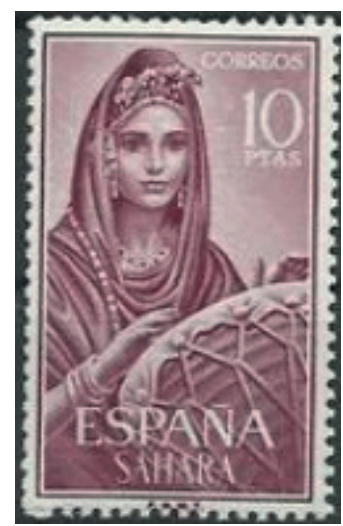

Imagen 12. Sáhara Español (1964). Músicos indígenas

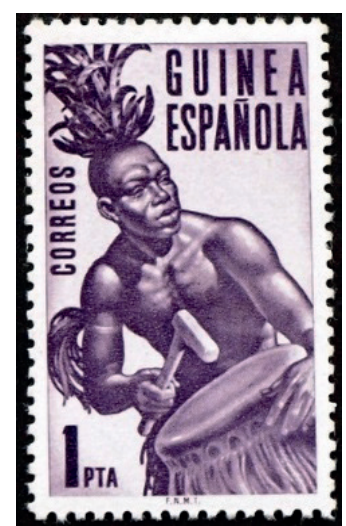

Imagen 13. Guinea Española (1953). Tipos indígenas 
Otros temas de menor importancia que aparecen como principales, en un porcentaje inferior ya al $5 \%$ del total, son los motivos postales $(4,9 \% ; 33$ sellos) y los personajes ilustres $(4,5 \% ; 30$ sellos $)$.

Si nos fijamos en las temáticas principales más presentes dentro de cada colonia, más allá de lo ya comentado, es destacable que el cristianismo solo es un tema frecuente en los sellos de Guinea Española (9,1\% dentro de esta colonia; 15 sellos), mientras que no se muestra en absoluto en los sellos de Marruecos Español y apenas en los de $\mathrm{AOE}(1,1 \% ; 3$ sellos). La razón es que Marruecos es un país islámico, al igual que la población del área adyacente de $\mathrm{AOE}$, mientras que Guinea Española, habitada por población subsahariana, fundamentalmente de creencias animistas, fue un área de evangelización cristiana española, lo que se refleja en los sellos postales de la colonia (Imágenes 14-16).

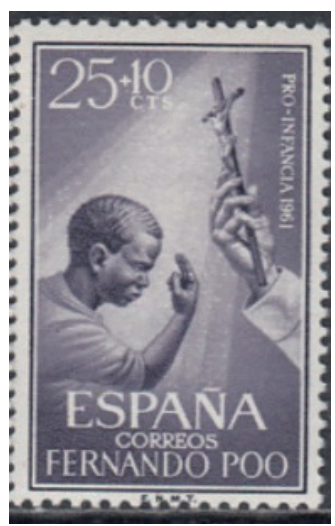

Imagen 14. Fernando Poo (1961). Evangelización

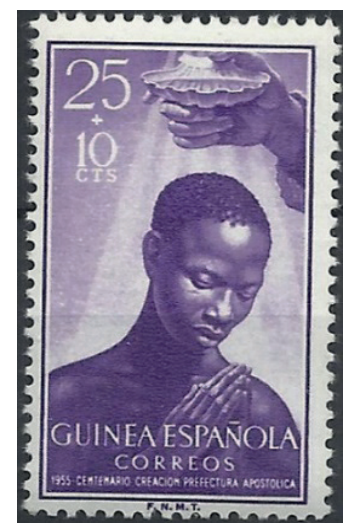

Imagen 15. Guinea Española (1955).

Centenario de la prefectura apostólica de Fernando Poo, Annobón y Corisco. Bautismo

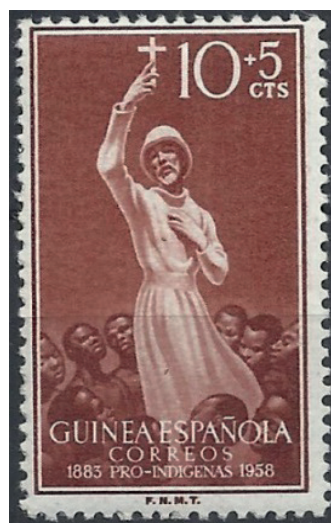

Imagen 16. Guinea Española

(1958). Misionero

Como se explicó en el epígrafe "Fuentes y metodología", se han codificado también los sellos analizados incluyendo una categoría de temas secundarios, que permite definir de forma más completa cuáles son los asuntos que se muestran en los sellos. Para evitar un exceso de tablas, se hace a continuación un análisis conjunto de los cinco temas principales y secundarios más presentes, en el conjunto de las áreas coloniales (Tabla 3).

Tabla 3. Los cinco temas principales y secundarios más presentes ( $\%$ en el conjunto de las colonias)

\begin{tabular}{clclc}
\hline $\begin{array}{c}\text { Posición según } \\
\text { presencia }\end{array}$ & \multicolumn{1}{c}{ Tema principal } & $\begin{array}{c}\text { \% en conjunto } \\
\text { de colonias }\end{array}$ & Tema secundario & $\begin{array}{c}\text { \% en conjun- } \\
\text { to de colonias }\end{array}$ \\
\hline $\mathbf{1}$ & Flora y fauna & $27,1 \%$ & Tipos indígenas & $30,9 \%$ \\
\hline $\mathbf{2}$ & Sanidad & $8,4 \%$ & Infancia & $8,9 \%$ \\
\hline $\mathbf{3}$ & Pueblos y arquitectura civil & $8,2 \%$ & Pueblos y arquitectura civil & $7,5 \%$ \\
\hline $\mathbf{4}$ & Tipos indígenas & $5,5 \%$ & Efemérides / eventos & $6,1 \%$ \\
\hline $\mathbf{5}$ & Cultura y folclore autóctono & $5,1 \%$ & Personajes ilustres & $5,3 \%$ \\
\hline
\end{tabular}

Fuente: Elaboración propia

A la vista de estos datos, "Flora y fauna" es el tema más empleado con diferencia en el conjunto de las colonias africanas españolas $(27,1 \%)$, pero la temática de "Tipos indígenas" tiene una importante presencia si valoramos su aparición como tema principal en un 5,5\% del total de sellos analizados y un 30,9\% como secundario (36,4 puntos de presencia en total). En tercer lugar, la categoría de "Pueblos y arquitectura civil" se observa en el $8,2 \%$ de los sellos como tema principal y en el 7,5\% como secundario, por lo que tiene un destacado peso total ( 15,7 puntos). "Sanidad" ( $8,4 \%$ como tema principal) e "Infancia" ( $8,9 \%$ como secundario) tienen su propia relevancia, como se ha comentado (Imágenes 17-18). 


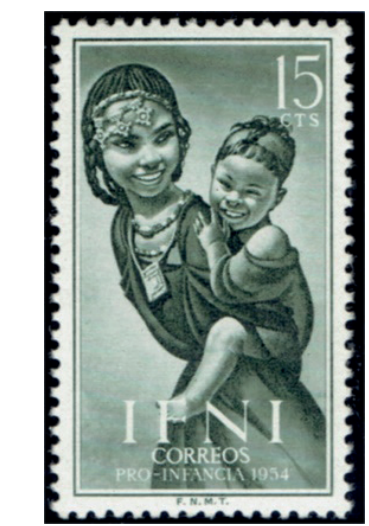

Imagen 17. Ifni (1954). Niños indígenas.

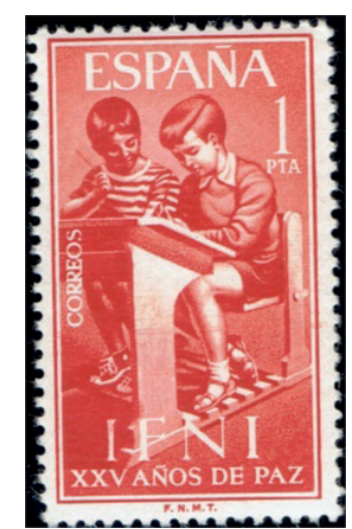

Imagen 18. Ifni (1965). XXV años de paz. Enseñanza escolar

Los sellos que hacen referencia a "Efemérides y eventos" (Imágenes 20-23) tienen un peso del 6,1\%, seguidos de las de "Personajes ilustres" (5,3\%) (Imágenes 20 y 23) entre las temáticas secundarias.

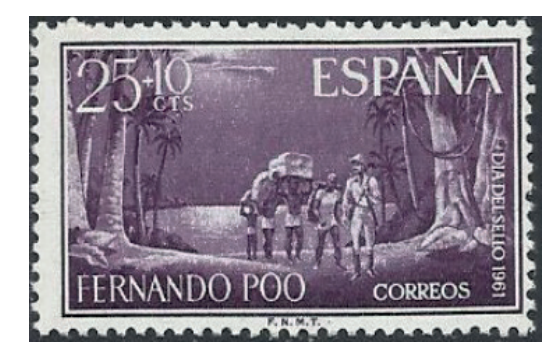

Imagen 19. Fernando Poo (1961). Porteadores

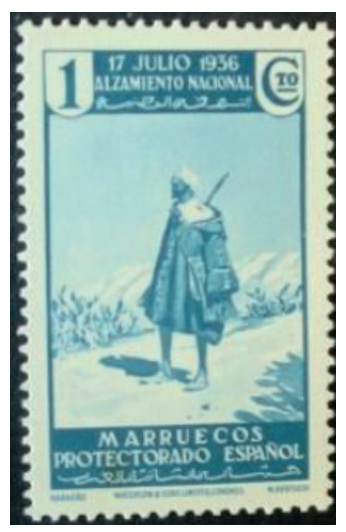

Imagen 21. Marruecos Español

(1937). I Aniversario del alzamiento nacional. Harkeño

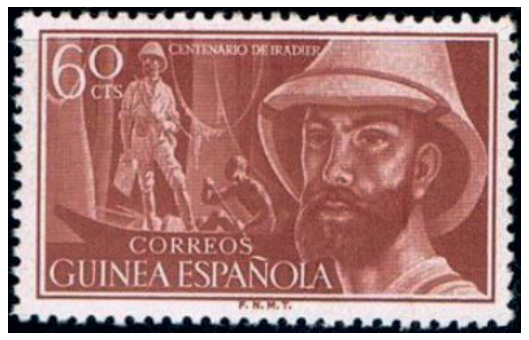

Imagen 20. Guinea Española (1955).

Centenario del nacimiento del explorador Manuel Iradier y Bulfy

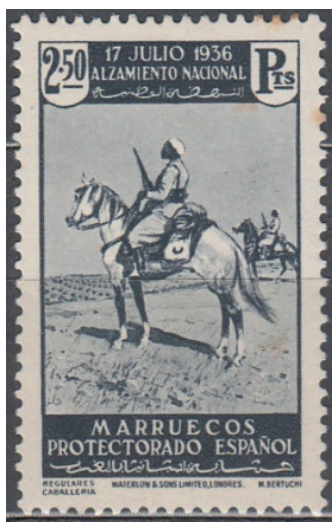

Imagen 22. Marruecos Español (1937). I Aniversario del alzamiento nacional. Regulares. Caballería

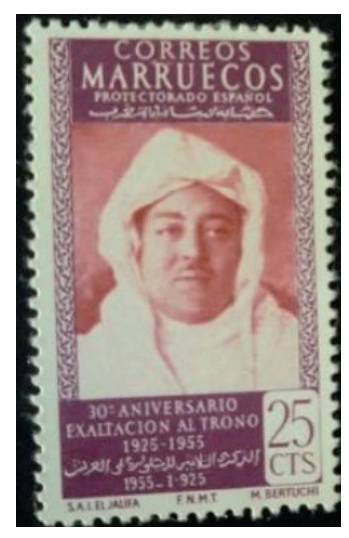

Imagen 23. Marruecos Español (1955). XXX Aniversario de la Exaltación al Trono de S.A. el Jalifa.

\subsection{Las actitudes de la metrópoli hacia las colonias}

Una vez analizadas las categorías temáticas primarias y secundarias presentes en los sellos analizados, se trata ahora de realizar una observación de conjunto, intentando responder a la siguiente pregunta: ¿qué actitud de la metrópoli española hacia las diferentes áreas coloniales nos transmite cada sello? Esta es la variable de análisis con mayor carga propagandística, ya que determina qué es lo que pretende mostrar el estado emisor de sí mismo al receptor. El resultado de este análisis se presenta en la Tabla 4. 
Tabla 4. Las actitudes de la metrópolis hacia las colonias $\left(\mathrm{N}^{\circ}\right.$ y \%)

\begin{tabular}{|c|c|c|c|c|c|c|c|c|}
\hline \multirow{2}{*}{\begin{tabular}{|l|}
\multicolumn{1}{|c|}{ COLONIA } \\
$\begin{array}{l}\text { ACTITUD DE LA ME- } \\
\text { TRÓPOLI }\end{array}$ \\
\end{tabular}} & \multicolumn{2}{|c|}{$\begin{array}{l}\text { AOE (SÁHA- } \\
\text { RA+IFNI) }\end{array}$} & \multicolumn{2}{|c|}{$\begin{array}{l}\text { GUINEA ESP. } \\
\text { (FERNANDO POO } \\
\text { + RÍO MUNI) }\end{array}$} & \multicolumn{2}{|c|}{$\begin{array}{c}\text { MARRUECOS } \\
\text { ESP. + TÁNGER }\end{array}$} & \multicolumn{2}{|c|}{ TOTAL } \\
\hline & $N^{o}$ & $\begin{array}{l}\text { \% dentro } \\
\text { de colonia }\end{array}$ & $N^{o}$ & $\begin{array}{l}\text { \% dentro de } \\
\text { colonia }\end{array}$ & $N^{o}$ & $\begin{array}{c}\text { \% dentro } \\
\text { de colonia }\end{array}$ & $N^{o}$ & $\begin{array}{c}\text { \% dentro } \\
\text { de colonia }\end{array}$ \\
\hline Neutra o no se identifica & 138 & $50,0 \%$ & 78 & $47,6 \%$ & 38 & $16,7 \%$ & 254 & $38,1 \%$ \\
\hline Deja vivir libre & 55 & $19,9 \%$ & 17 & $10,4 \%$ & 146 & $64,3 \%$ & 218 & $32,7 \%$ \\
\hline Domina & 37 & $13,4 \%$ & 32 & $19,5 \%$ & 18 & $7,9 \%$ & 87 & $13,0 \%$ \\
\hline Civiliza & 40 & $14,5 \%$ & 14 & $8,5 \%$ & 24 & $10,6 \%$ & 78 & $11,7 \%$ \\
\hline Evangeliza & 2 & $0,7 \%$ & 20 & $12,2 \%$ & 0 & $0,0 \%$ & 22 & $3,3 \%$ \\
\hline $\begin{array}{l}\text { Conviven colonizador y } \\
\text { colonizado }\end{array}$ & 4 & $1,4 \%$ & 3 & $1,8 \%$ & 1 & $0,4 \%$ & 8 & $1,2 \%$ \\
\hline Oprime & 0 & $0,0 \%$ & 0 & $0,0 \%$ & 0 & $0,0 \%$ & $\mathbf{0}$ & $0,0 \%$ \\
\hline Total & 276 & $100,0 \%$ & 164 & $100,0 \%$ & 227 & $100,0 \%$ & 667 & $100,0 \%$ \\
\hline
\end{tabular}

Fuente: Elaboración propia

Los resultados de esta tabla se han ordenado de forma descendente, a partir del mayor número de unidades perteneciente a una actitud y se pueden observar más claramente en el Gráfico 4. Así, en un 38,1\% de los sellos analizados no ha sido posible encontrar una actitud determinada o se ha considerado neutra. Es el caso, por ejemplo, de la mayor parte de los sellos dedicados a "Flora y fauna", que tienen un peso importante, como se ha visto, en el conjunto de las temáticas presentes.

Gráfico 4. Las actitudes de la metrópolis hacia las colonias

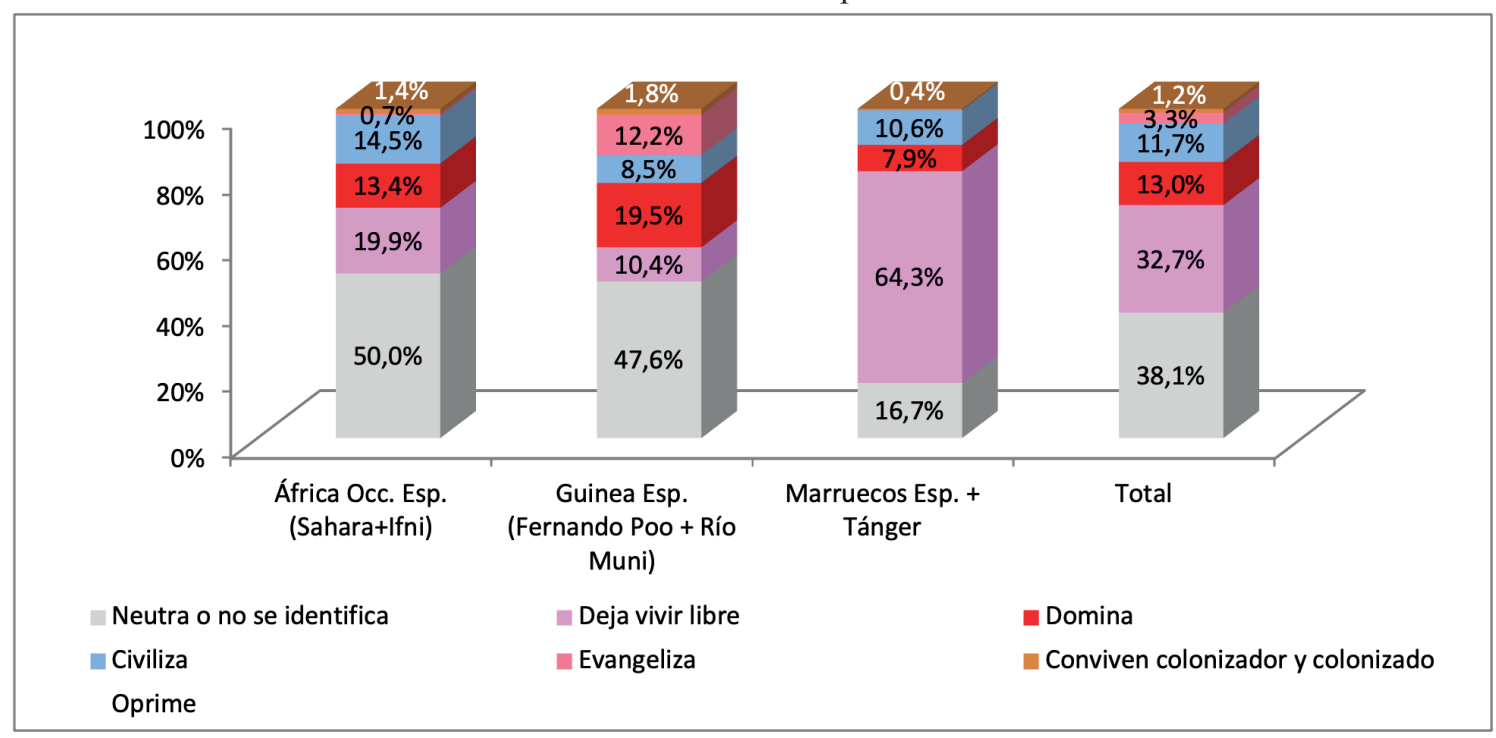

Fuente: Elaboración propia a partir de la Tabla 4

La segunda actitud (la primera con contenido) sería la que "Deja vivir libre" al colonizado, con un 32,7\% del total. Se trata de una categoría que presenta al colonizado llevando su vida, sin aparente interferencia de la metrópoli. Ejemplo de ello serían los sellos dedicados a "Cultura y folclore autóctono" o "Pueblos y arquitectura civil", así como "Economía agrícola, caza y pesca" (Imágenes 24-26), donde el nativo sigue llevando su forma de vida ancestral de forma supuestamente autónoma. Sin embargo, hay que señalar que hay importantes diferencias entre áreas coloniales en esta categoría, ya que es en Marruecos Español donde tiene un peso de casi dos tercios del total (64,3\%). En cambio, en Guinea Española solo tiene una incidencia del $10,4 \%$ del total de las actitudes dentro de la propia colonia, y un 19,9\% en África Occidental. 


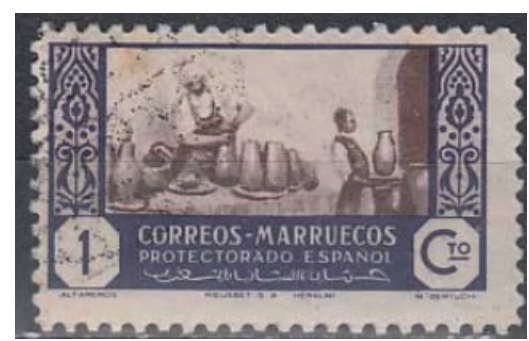

Imagen 24. Marruecos Español

(1946). Artesanía. Alfareros

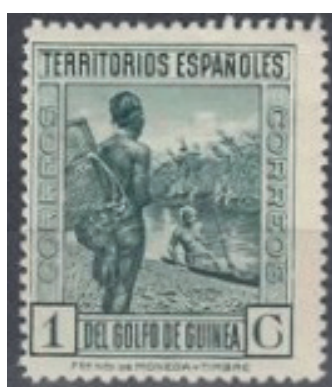

Imagen 25. Guinea Española

(1931). Tipos indígenas

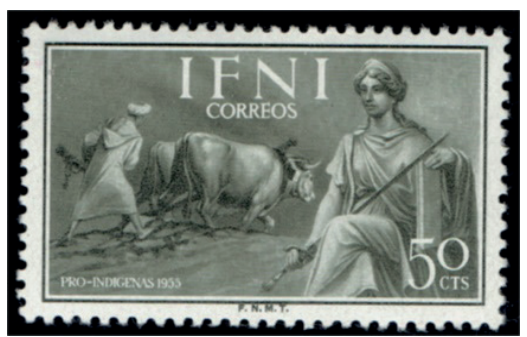

Imagen 26. Ifni (1954). Agricultura

La tercera actitud, por número de unidades totales, sería aquella que "Domina" (13\%), donde el colonizado se ve sometido de alguna forma al colonizador, mostrándose claramente que la presencia de este es de señorío o superioridad sobre el colonizado. Los temas que inciden es esta actitud son la "Temática militar", la presencia de "Símbolos del estado o la colonia" y la de determinados "Personajes ilustres" que representan al Jefe de Estado actual en cada momento o a reyes o personajes que contribuyeron a colonizar el territorio en cuestión (Imágenes 27-32). En Marruecos Español es donde menos peso tiene, con un 7,9\% del total dentro de las actitudes presentes en la propia colonia, lo que incide en el trato diferenciado de la metrópoli, más laxo, en esta zona respecto a otras áreas coloniales.

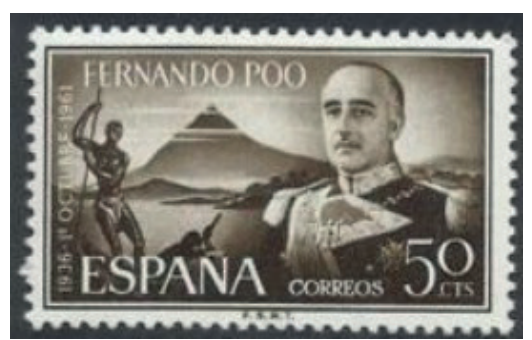

Imagen 27. Fernando Poo (1961). XXV Aniversario de la exaltación del general Franco a la jefatura del Estado

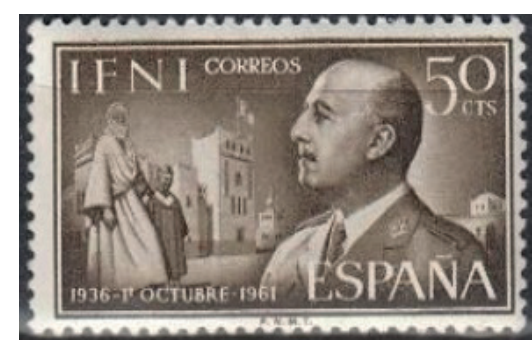

Imagen 30. Ifni (1961). XXV

Aniversario de la exaltación del general Franco a la jefatura del Estado

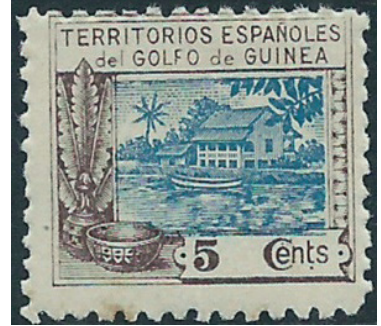

Imagen 28. Guinea Española

(1924). Casa de Nipa. Residencia del gobernador

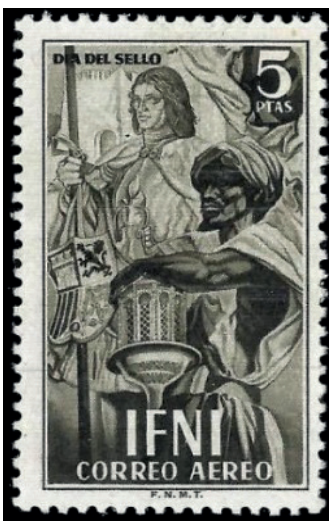

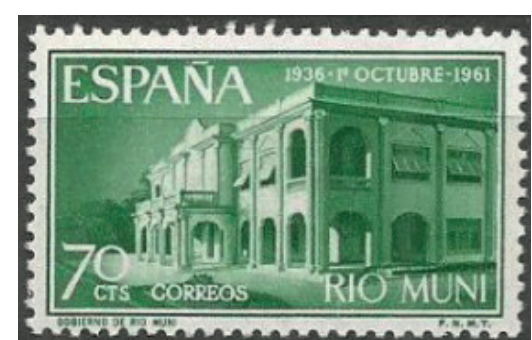

Imagen 29. Río Muni (1961). XXV Aniversario de la exaltación del general Franco a la jefatura del Estado. Palacio gubernamental

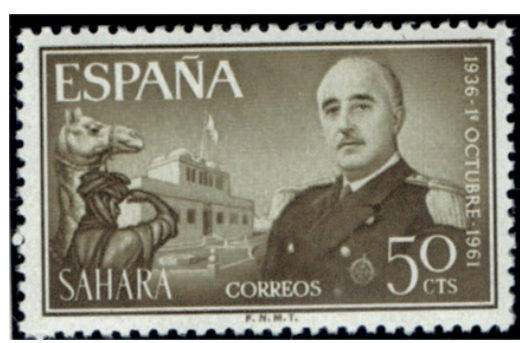

Imagen 32. Sáhara (1961). XXV

Aniversario de la exaltación del general Franco a la jefatura del Estado

Imagen 31. Ifni (1950). Lope Sancho de

Valenzuela en acto de recibir la sumisión

de los caídes de la región Uad Nun

En cuarto lugar aparece la actitud "Civiliza" (11,7\%), donde se hace hincapié en los beneficios que la metrópoli aporta a la colonia en forma de educación, sanidad, infraestructuras, desarrollo económico o deportes, sin que haya grandes diferencias entre las áreas coloniales analizadas (Imágenes 33-38). 


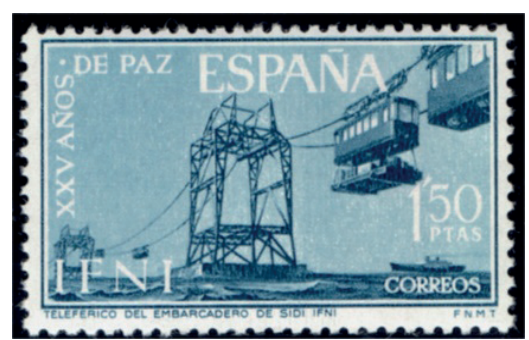

Imagen 33. Ifni (1965). XXV años de paz. Descarga mecánica de navíos

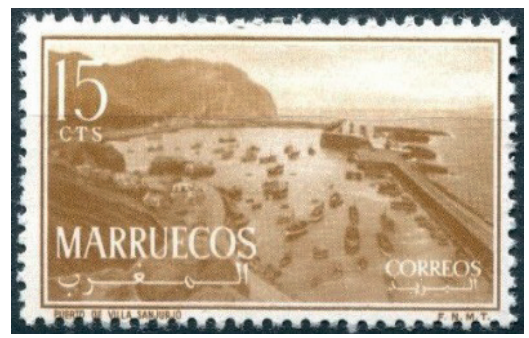

Imagen 36. Marruecos (1956).

Puerto de Villa Sanjurjo

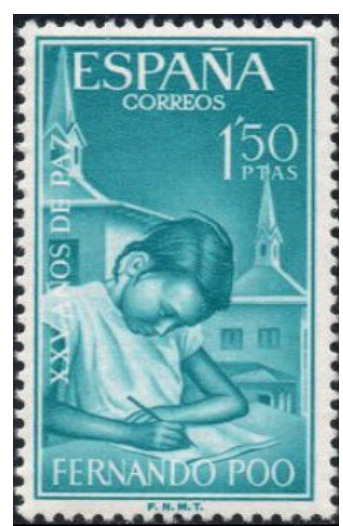

Imagen 34. Fernando Poo (1965).

XXV años de paz. Escuelas

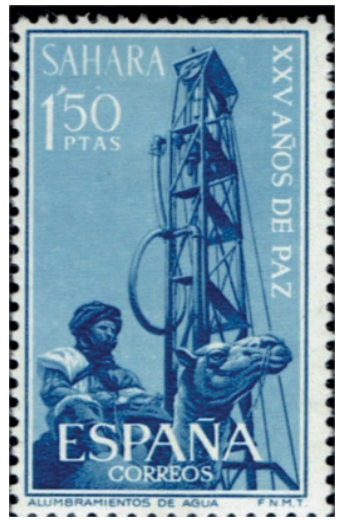

Imagen 37. Sáhara (1965). XXV

años de paz. Prospecciones

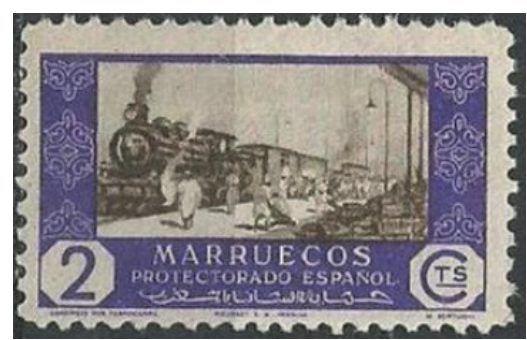

Imagen 35. Marruecos Español (1948). Comercio por ferrocarril

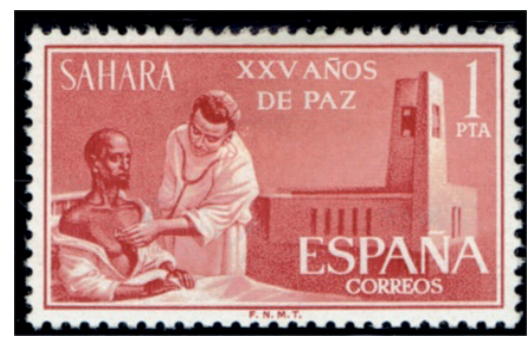

Imagen 38. Sáhara (1965). XXV años de paz. Asistencia médica

Ya con un peso muy inferior tendríamos la actitud "Evangeliza" (3,3\%), que se da en el área de Guinea Española (12,2\%), pero no en Marruecos Español y apenas en AOE.

Finalmente, es muy destacable que la actitud "Conviven colonizador y colonizado" escasamente se muestre en los sellos de las colonias $(1,2 \%)$, coincidiendo con la realización conjunta de algunas actividades deportivas.

También es reseñable que la actitud más negativa de "Oprime" no se haya observado ni una sola vez. Sin duda, el papel del sello como transmisor de los valores positivos que el país emisor quiere presentar a sus diferentes públicos (locales e internacionales) tiene mucho que ver en ello.

\section{Conclusiones}

Se trata ahora de poner en relación todo lo visto con anterioridad, vinculándolo con la finalidad propagandística de los sellos analizados. La primera conclusión tiene que ver con los temas principales y secundarios presentes en el conjunto de las colonias. Hemos visto que son "Flora y fauna", "Tipos indígenas" y "Pueblos y arquitectura civil". La preponderancia de estos temas no es casual. El estado pretendía con ello presentar el exotismo de sus dominios, dando una sensación de pertenencia a un imperio a sus ciudadanos, respetando además al colonizado al mostrar temas neutros, cotidianos de su entorno, sin soliviantarlo con un exceso de composiciones de dominio o aculturación. Este aspecto tiene otra finalidad, declarada en el caso del Marruecos Español, como es el fomento del turismo, dada su cercanía geográfica.

La segunda conclusión se refiere a la actitud de la metrópoli manifestada en los sellos. Si sumamos la actitud "neutra o no identificada" con la que "deja vivir libremente" y la que muestra "convivencia entre colonizador y colonizado", totalizan un $72 \%$ de los sellos analizados. Se trata de emplear una propaganda blanca que muestre valores positivos, que no ofendan al colonizado. De cara al otro público, que es la población de la metrópoli, le muestra la benevolencia del régimen y de su dominio paternal, el exotismo y la diversidad de las áreas colonizadas pero, si añadimos las actitudes de civilizar y evangelizar (15\% entre ambas), se quiere presentar la colonización como algo beneficioso para el colonizado (desde el punto de vista del colonizador, claro está) que, además, forma parte de una determinada visión de la misión de España en el mundo. También contribuye esta perspectiva a afianzar entre la población de la metrópoli la conformación de esa "comunidad imaginada", muy vinculada al fomento del nacionalismo patrio, gracias a la sujeción a una serie de valores 
proyectados por el poder político. Finalmente, la escasez del mensaje de dominio (13\%) y la inexistencia de un mensaje de opresión confirman que se trata de mostrar la mejor cara del gobierno español en relación con la colonización.

En tercer lugar, esta visión global debe ser particularizada para cada área colonial, ya que se ha observado que los mensajes son diferentes, puesto que las características de sus habitantes y la percepción que se tiene de ellos en la metrópoli también lo son. En el área de Marruecos Español y Tánger los sellos muestran una relación amable, una vida en libertad en sus tradiciones idealizadas, tan apenas perturbada por la acción de la metrópoli, salvo para mejorar sus condiciones de vida (con sanidad, educación, transportes e infraestructuras), permitiendo referencias a la autoridad del Jalifa, con quien las relaciones políticas son correctas. Además, el régimen franquista paga con esta libertad los servicios prestados por los líderes marroquíes al bando sublevado durante la Guerra Civil. Se trata de mantener la paz social y de hacer valer la hermandad hispano-árabe, propiciada por el franquismo y el africanismo. En cambio, el mensaje en relación con la Guinea Española es otro. La diferencia étnica se pone especialmente de relieve con la abundancia de sellos sobre tipos indígenas. Hay menos escrúpulos para mostrar el dominio de la metrópoli (en el 19,5\% de los sellos de esta área), así como la acción evangelizadora (12,2\%), algo que no se da en las restantes zonas de mayoría islámica. Finalmente, en el área de AOE el mensaje es intermedio: se quiere mostrar lo positiva que es la presencia civilizadora de la metrópoli (14,5\% de sus sellos), pero la mitad de ellos son neutros en su mensaje, sin que exista la misma complicidad del poder que con el caso marroquí.

Como reflexión final, creemos que ha quedado demostrado que los sellos postales son una fuente útil para mostrar las estrategias de comunicación ideológica y cultural de los valores de la metrópoli española en relación con sus áreas coloniales africanas. Esto se concreta en una visión aparentemente neutra, con el predominio de elementos exóticos, natural y culturalmente hablando, pero que, cuando entra a mostrar otros aspectos, aumenta claramente el peso de los elementos propagandísticos, con los matices de tratamiento en las diversas áreas coloniales analizadas.

\section{Referencias bibliográficas}

Adedze, A. (2004). "Re-Presenting Africa: Commemorative Postage Stamps of the Colonial Exhibition of Paris (1931)", African Arts, v.2, n.37, pp. 58-61; 94-95. https://doi.org/10.1162/afar.2004.37.2.58

Altman, D. (1991). Paper Ambassadors. The Politics of Stamps. Australia: Angus \& Robertson. ISBN: 0207162174.

Álvarez-Chillida, G.; Nerín, G. (2018). “Guinea Ecuatorial: el legado de la colonización española”. Ayer, v. 1, n. 109, pp. 13-32.

Anderson, B. (2006). Imagined Communities. Reflections on the Origin and Spread of Nationalism. Londres: Verso. ISBN: 9780860910596.

Berelson, B. (1952). Content Analysis in Communication Research. Nueva York: Free Press. ISBN: 0028412109.

Brunn, S. (2001). "Stamps as Iconography: Celebrating the Independence of New European and Central Asian States". GeoJournal, v. 52, n. 1, pp. 315-323.

Campos-Serrano, A. (2000). "El régimen colonial franquista en el golfo de Guinea". Revista Jurídica, 3, pp. 79-108.

Child, J. (2005). "The politics and semiotics of the smallest icons of popular culture: Latin American Postage Stamps". Latin American Research Review, v.40, n.1, pp. 108-137. https://doi.org/10.1353/lar.2005.0003

Cusack, I. (2005). "Tiny transmitters of nationalist and colonial ideology: the postage stamps of Portugal and its Empire". Nations and Nationalism, v.4, n.11, pp. 591-612. https://doi.org/10.1111/j.1469-8129.2005.00221.x

De-Madariaga, M. R. (2013). Marruecos, ese gran desconocido. Breve historia del protectorado español. Madrid: Alianza Editorial. ISBN: 978 8420610160.

Deans, P.; Dobson, H. (2005). "East Asian Postage Stamps as Socio-Political Artefacts". East Asia, v.2, n.22, pp. 3-7. https://doi.org/10.1007/s12140-005-0006-6

España (1944). "Orden de 5 de Julio de 1944 por la que se fija el plan iconográfico en la elaboración de sellos de correos". BOE n. 191, 9 de julio. https://www.boe.es/datos/pdfs/BOE//1944/191/A05303-05304.pdf

García, L.B. (2010). "Las representaciones de la filatelia franquista". Historia Contemporánea, 40, pp. 217-245.

Gozalbes, E. (2011). "El Protectorado Español de Marruecos (1912-1956) en las imágenes de los sellos de correos". Miscelánea de estudios árabes y hebraicos. Sección Arabe-Islám, 60, pp. 153-174.

Hoek, L. (2002). "Timbres-poste et intermédialité sémiotique des rapports texte/image". Protée: Revue internationale de théories et de pratiques sémiotiques. Sémiologie et herméneutique du timbre-poste, v.30, n.2, pp. 33-44. https://doi.or $\mathrm{g} / 10.1080 / 02666286.1993 .10435479$

Hoek, L.; Scott, D. (1993). "Une révolution en miniature: le timbre-poste commémoratif du bicentenaire de la Révolution française". Word \& Image, v.IX, n.2, pp. 97-113.

Hoyo, H. (2010). "Posting Nationalism Postage Stamps as Carriers of Nationalist Messages". En: Burbick, J.; Glass, W.(eds.). Beyond Imagined Uniqueness: Nationalisms in contemporary perspectives. Cambridge: Cambridge Scholars Publishing, pp. 67-92. ISBN: 9781443824095. 
Jowett, G.; O’Donnell, V. (2012). Propaganda and Persuasion. Thousand Oaks (EE.UU.): Sage Publications. ISBN: 978 1412977821.

Krippendorf, K. (1980). Content Analysis: An Introduction to its Methodologies. Londres: Sage. ISBN: 9780803914971.

Lutz, C.; Collins, J. (1993). Reading National Geographic. Chicago: The University Chicago Press. ISBN: 0226497240.

Mirzoeff, N. (1998). “What Is Visual Culture?”. En: Mirzoeff, N. The Visual Cultural Reader. Londres: Routledge, pp. 3-13. ISBN: 0415141338.

Moriente, D. (2013). "Simulacro de un trópico apacible”. En: Navarro, G. (ed.). Autorretratos del Estado. El sello postal del franquismo. Cuenca: Ediciones de la Universidad de Castilla-La Mancha, pp. 122-147. ISBN: 9788490440452.

Navarro, G. (2010). Autorretratos del Estado. Una aproximación al sello postal del franquismo como medio de emisión de mensajes ideológicos (1936-1975). Cuenca: Ed. Universidad Castilla-La Mancha. ISBN: 9788484277934.

Navarro, G. (2013). "El sello postal del franquismo como autorretrato del Estado". En: Navarro, G. (ed.). Autorretratos del Estado. El sello postal del franquismo. Cuenca: Ed. de la Universidad de Castilla-La Mancha, pp. 12-19. ISBN: 9788490440452.

Parón, C. (2018). El orden mundial. https://elordenmundial.com/amigos-con-intereses-espana-y-el-mundo-arabe/

Pelissier, R. (1964). Los territorios españoles de África. Madrid: Consejo Superior de Investigaciones Científicas. http:// www.opensourceguinea.org/2012/11/pelissier-rene-los-territorios.html

Pizarroso, A. (1999). "La historia de la propaganda: una aproximación metodológica". Historia y Comunicación Social, 4, pp. $145-171$

Raento, P. (2006). “Communicating geopolitics through postage stamps: The case of Finland”. Geopolitics, v.4, n.11, pp. 601-629. https://doi.org/10.1080/14650040600890750

Raento, P.; Brunn, S. (2005). "Visualizing Finland: Postage stamps as political messengers". Geografiska Annaler, v.2, n.87 B, p. 145-163. https://doi.org/10.1111/j.0435-3684.2005.00188.x

Raento, P.; Brunn, S. (2008). "Picturing a nation: Finland on postage stamps, 1917-2000”. National Identities, v.1, n.10, p. 49-75. https://doi.org/10.1080/14608940701819777

Reid, D. (1984). "The Symbolism of Postage Stamps: A Source for the Historian”. Journal of Contemporary History, v. 19, n.2, pp. 223-249. https://doi.org/10.1177/002200948401900204

Reig, R. (2004). Dioses y diablos mediáticos. Cómo manipula el Poder a través de los medios de comunicación. Barcelona: Ed. Urano. ISBN: 8479535520.

Rose, G. (2001). Visual Methodologies: An Introduction to the Interpretation of Visual Materials. Londres: SAGE Publications. ISBN: 0761966641.

Satué, E. (2011). El factor del diseño en la cultura de la imagen y en la imagen de la cultura. Madrid: Alianza. ISBN: 9788420651262.

Schwarzenbach, A. (1999). Portraits of the Nation: Stamps, Coins, and Banknotes in Belgium and Switzerland, $1880-$ 1945. Nueva York: European University Studies. ISBN: 9780820446141.

Scott, D. (2002). "Sémiologie et herméneutique du timbre-poste". Protée: Revue internationale de théories et de pratiques sémiotiques. Sémiologie et herméneutique du timbre-poste, v.2, n.30, pp. 4-7. https://doi.org/10.7202/006726ar

Stoetzer, C. (1953). Postage Stamps as Propaganda. Washington: Public Affairs Press. ISBN: 9789333355483.

Suárez-Blanco, S. (1997). "Las colonias españolas en África durante el primer franquismo (1939-1959). Algunas reflexiones". Espacio, Tiempo y Forma, v.V, n.10, pp. 315-331.

Vilar, J. (2005). "Franquismo y descolonización española en África”. Historia Contemporánea, 30, pp. 129-158.

\section{Notas}

1. Todas las imágenes de sellos postales españoles utilizadas en este trabajo han sido autorizadas por Correos cumpliendo sus especificaciones técnicas. 